\title{
REPRESENTATION OF THE NEW REGIME TRANSITION TOWARDS THE REFORMATION ERA IN THE TEMBOK PAK RAMBO SHORT STORY BY TAUFIK IKHRAM JAMIL: INTERTEXTUALITY STUDY
}

\author{
Representasi Transisi Orde Baru terhadap Era Reformasi dalam Cerita Pendek Tembok Pak Rambo
} Karya Ikhram Jamil: Sebuah Studi Interteks

\author{
NI LUH AYU SUKMAWATI \\ Program Studi Magister Kajian Sastra dan Budaya \\ Fakultas Ilmu Budaya Universitas Airlangga \\ Jl. Dharmawangsa Dalam Selatan, Surabaya 60286 \\ e-mail: ni.luh.ayu-2018@fib.unair.ac.id
}

\begin{abstract}
The transition era between the New Order Era to the Reformation Era in Indonesia in 1998 became one of the popular themes for Indonesian writers. One of the works entitled Tembok Pak Rambo inserted elements of historical facts that occurred in Indonesia. The representation of the obscurity of the new order in this short story cannot be read only with heuristic readings, therefore a theory is needed to explore more profound the significance of the story. This paper utilizes the intertextuality approach in dismantling the veiled meanings in the story. The results showed that the short story represents two Indonesian leaders in the era of the new order transition to the reform era. This representation appears when aligned with a book called The Long Way of Indonesia Towards Democracy written by B. J. Habibie. Moreover, the short story titled Tembok Pak Rambo is not just about the hegemony between the ruler to his subordinates, but how the Indonesian writers were trying to criticism on the government and the historical facts that happened in 1998.
\end{abstract}

Keywords: Intertextuality, New Order, Reformation, Short Story

Abstrak: Transisi antara era Orde Baru ke Reformasi di Indonesia pada atahun 1998 menjadi salah satu topik yang gencar diangkat oleh para penulis Indonesia. Salah satu karya sastra berjudul Tembok Pak Rambo memasukkan unsur fakta historis yang pernah terjadi di Indonesia. Kerancuan era Order Baru dalam cerita pendek ini tidak dapat diraba melalui pembacaan heuritik semata, sehingga diperlukan sebuah teori guna mengungkap pemaknaan sesungguhnya pada cerita tersebut. Hasil kajian menunjukkan bahwa cerita pendek tersebut merepresentasikan dua pemimpin negara Indonesia pada masa transisi kedua era. Representasi ini muncul ketika disejajarkan dengan buku berjudul The Long Way of Indonesia Towards Democracy karya B. J. Habibie. Cerita pendek Tembok Pak Rambo bukan hanya mengenai hegemoni antara pemimpin dengan bawahannya tetapi juga menjadi cara penulis Indonesia mengkritisi pemerintah dan fakta historis yang terjadi pada tahun 1998.

Kata-kata Kunci: Cerita Pendek, Interteks, Orde Baru, Reformasi

Jurnal Lakon: Kajian Sastra dan Budaya 


\section{INTRODUCTION}

The transition period of the new order regime towards the reform era has received global attention. The sinking and silence of the mass media during the reign of the New Order regime became a dark point of journalism in distributing news actuality. With the ever-increasing tradition of defense against the actuality of the news during the regime's transition period, it seems that it provides a separate loophole for critics to provide criticism on sociopolitical issues.

The tendency to display criticism on socio-political issues is also a trend for writers in Indonesia. Space becomes a forum for writers to pour recorded historical facts. Documentary meaning presented by Indonesian authors is a result of the relationship between work and the social context of creation, in this case, the socio-political influences or cultural tendencies reflected in a work (Chasanah, 2007). Thus, literature has become a contemporary era and has a strong connection with historical facts. Indonesian writers who were keen to write sharp criticisms during the new order include Mochtar Lubis, Pramoedya Ananta Toer, W.S. Rendra, and other writers. Criticism was also made in creation literature during the transition from the new order to the reform era. Some writers who focus on social and political issues that occurred during the New Order regime created short stories that focused on the central figure of the regime, namely Suharto.

A collection of short stories entitled Soeharto dalam Cerpen Indonesia (SDCI) (2001) became one of the proofs of the existence of writers who had strong intuition in capturing events that occurred during the New Order era. This collection of short stories consists of 17 short stories written by prominent writers, such as Agus Noor, Seno Gumira Ajidarma, F. Rahadi, Taufik Ikhram Jamil, and other writers.

The representation of Suharto as a symbol of the New Order regime will be seen directly through the front cover, starting from the title to the cover of the book that has a portrait of Suharto wearing the clothes of the Javanese kings. Furthermore, by reviewing the literary creative-reaction representation of SDCI, previous research has found that there are five Soeharto imageries as literary creative reactions to the New Order rulers, such as the image of Suharto as an animal, fictional figure, puppeteer, puppet, village head (Chasanah, 2007). By showing the results that refer to actions by using the coercive apparatus, the ruler's hegemony thus becomes domination at that time.

In its continuation from the New Order era to the period of reform, journalists, writers, acting, and others are increasingly open and have the freedom to pour their recordings of historical facts that occurred in the New Order. What is interesting is the books written by elites who have an important role in the course of regime change in Indonesia. One of the trending books in 2006 was a book entitled Detik-Detik yang Menentukan: The Long Way of Indonesia Towards Democracy (DDYM) written by B. J. Habibie. The author himself is someone who has an important role in the journey of the new order to the reform era, because he served as the State Minister of Research and Technology for 20 years (1978-1998), 7th vice president with a term of March-May 1998, and became the 3rd Indonesian president replaced the Indonesian president before Soeharto, 
coinciding with the new order that collapsed and was replaced by the reform era. In his book, B. J. Habibie wrote historical facts through what he experienced while serving in the Indonesian government until the end of his tenure as the 3rd Indonesian president.

Furthermore, the authors aim to analyze the interrelationships between texts in one of the short stories in SDCI entitled Tembok Pak Rambo (TPR) (2001) by Taufik Ikhram Jamil with the book DDYM (2006) by B. J. Habibie. The assumption that the interrelationship between texts is both supported by previous research that shows the figures present in the TPR short story is the image of Soeharto and B. J. Habibie (Chasanah, 2007). The linkage of the text will be examined with a focus on the meaning assumed by the TPR short story to have the absorption and transformation of stories from historical facts at the turn of the new order period as evidenced by B. J. Habibie 's DDYM book.

Departing from these assumptions, the authors use the stages offered by the intertextuality approach. By utilizing this approach, the reader will get a deepening and expansion of the meaning of the text. This is similar to what expressed by Kristeva (Ratna, 2004), regarding the texts which are mosaic, absorption, and transformation of other texts, so that a text cannot be created without the intuition of the author in capturing events in the text. Furthermore, absorption or mosaic transformed into works that have aesthetic elements. By revealing the mosaic pieces, the meaning will be revealed to the values that exist in the transformation text.

\section{THEORETICAL REVIEW}

\section{Intertextuality}

The intertextuality approach has a function to explore and infer the value and meaning of a text in full. Reading will be said to be successful if it can capture the meaning presented by the text. At the reading stage, we recognize heuristic and hermeneutic readings (Ratna, 2004). At the heuristic level of reading, the reader will find meaning in general and has not reached the stage of deepening the meaning of the text. To achieve an expansion of meaning, the reader must be at the hermeneutical level, where the reader will arrange and find relationships based on the signs found. Intertextuality regards all texts, whether literary or not, as lacking in any kind of independent meaning. The very act of reading itself engages us with a network of textual relations, and it is the job of the reader to disentangle and discover the existing textual relations (Zohreh Ramin, 2014).

In interpreting the signs in the text, Riffaterre uses a hypogram to compare and relate the signs that exist in the previous texts (Ratna, 2004). The search for hypogram in the text certainly requires the carefulness of the reader to find its forming roots, so before determining the hypogram the writer determines the matrix and symbol in certain variants. Thus, in line with Kristeva's statement that the text can be concluded a mosaic transformed with forms of representation moving from an explicit text to implicit (Faruk, 2017). Thus, reading does not only produce meaning in general (meaning) like at the level of language but focuses more on the search for expanded meaning (significance). 
Structural Theory Semantic A. J. Greimas

The development of narratological theories contributes to the analysis of patterns that reach aspects of co-text or context. One of the semantic structural theories that have an advantage over character functions is the structuralsemantic theory by A.J.Greimas. The function of the character in this context is related to the act that moves a story. As a foundation, this theory is built on the basic assumption that narrative texts are composed of several analogous structural diagrams in linguistics originating from Ferdinand de Saussure on the one hand, and classical narrative theory by Vladimir Propp (Karnanta, 2015).

Thus Greimas focuses more on actions or actions than those that appear. Furthermore, according to Greimas, the action space consisting of subjects, objects, senders, helpers, recipients, and opponents is grouped into three pairs of binary opposition, namely Axis of Desire (Subjects with Objects), Axis of Power (Helper with Opponent), Axis of Knowledge (Sender and Receiver) (Setijowati, 2018). By utilizing the structural-semantic theory by A.J.Greimas the author will find an active relationship intended to support the existence of narrative structures.

\section{METHOD}

The data of this study are TPR short stories by Taufik Ikhram Jamil and the DDMY book by B. J. Habibi. The researcher will explore the intertextual relationship between the two works by utilizing the steps offered in analyzing the text with an intertextuality approach. First, the author will do heuristic readings to clarify the linguistic meaning of the two texts. The second is hermeneutic reading, which is an advanced process for analyzing meaning.

The meaning here in the meaning of literature is not only understood in terms of linguistic meaning (meaning) but more than that, namely the meaning of literature (significance) (Pradopo, 2000). At the stage of hermeneutic reading, there are four processes carried out, namely (1) describing the structure of the story that exists in the text using the structuralsemantic theory by A. J. Greimas.

This theory was chosen as a supporting theory because basically, the semantic theory offered by Riffatere was less able to describe consumption especially at the level of actions and grooves in a short story. The next stage is (2) determining the matrix and the model of the values obtained from the previous stages, (3) determining and comparing the hypograms of the two texts (4) with the results of the intertextual relationship with Kristeva's intertext approach. (5) and the latter determines the meaning (significance). Thus the meaning (significance) and values that exist in the transformation text will be known.

\section{DISCUSSION}

\section{Heuristic Reading of the Short Stories}

On reading the heuristic stage, the author can capture the core story of the TPR short story by Taufik Ikhram Jamil. The TPR short story tells the story of the main character named Pak Rambo who has the desire to build a wall as thick as possible so that it cannot be penetrated by the eyes of his people. Syam's figure is told as a subordinate from Mr. Rambo who was assigned to make a wall. Mr. Rambo

Jurnal Lakon: Kajian Sastra dan Budaya 
entrusted the construction of the wall because Syam was a graduate of the German state. However, in terms of making walls, the wall that was designed by Sham was repeatedly denied.

The wall was rejected by Mr. Rambo because Mr. Rambo wanted an ordinary wall made of cement and opaque bricks. One night, Mr. Rambo came to Syam's desk and explained about the thick wall that was very wanted by Pak Rambo, apparently to close Sham's eyes in seeing the poverty and injustice around him.

Syam was surprised by his arrival without being escorted by aides who were usually always on standby beside him. The next morning, Syam was made even more confused because Mr. Rambo turned into a different figure from what was seen last night. Syam's fears became more and more because he was about to be shot on the spot. Mr. Rambo was furious over the opaque wall design, different from what he had previously wanted. Syam was troubled by the thudding produced by the people who destroyed the walls and continued to be heard. Then, Mr. Rambo stressed that he would stop and convince Sham not to be afraid because the people considered that Syam was not guilty. Furthermore, the TPR short story ends with a sentence from Pak Rambo saying 'congratulations on fighting young conscience'.

\section{Structural-Semantic Analysis}

Analysis using the intertext approach deconstructs the dichotomy of markers and markers on conventional semiotics which considers work to be autonomous without the mosaic being the framework. Through the intertext perspective, the writer will prove that literary works must be placed within the framework of space and time in a concrete way, by using and utilizing other texts as the basis for the transformation text game.

Before determining the matrix, model, and meaning (significance) in the transformation text, the writer will do the analysis using the structural paradigm. Structural theory-semantics A.J. Greimas is used as a text surgery tool to find out the elements in TPR short stories, namely the function of action and value. This stage becomes important because the object of the research is a literary text in the form of short stories that have story elements that must be deepened first.

Relating to structural use-semantics by A.J. Greimas, the analysis departs from the three binary opposition pairs that exist in the text of the TPR short story transformation. In determining an active scheme, the author focuses on the core story and needs to be noted that figures do not always become roles in acting, a statement or idea can be an act. Following is the scheme of the acting relationship found in the TPR short story:

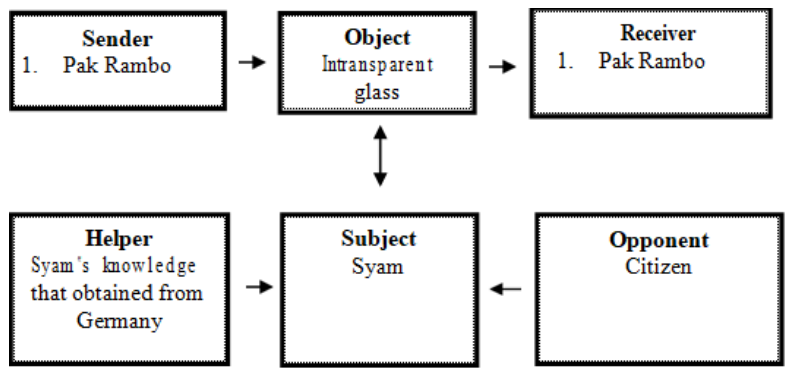

Figure 1 . The acting relationship found in the TPR short story

1. Subject

The determination of the subject is based on the existence of an act that receives the assignment from the sender. 
The agreement between the two deeds that binds between the two becomes the background to reach an object that you want to achieve. In the TPR short story, the Syam figure acts as a subject that is marked by the acceptance of the task of the sender, which is to make a wall that is not transparent.

\section{Objects}

Object is something that the sender wants to achieve and moves the story by assigning the subject to achieve it. With in-depth reading, the phrase "making a wall of invisibility" is found which always repeats and becomes a mission given by the sender to the subject. Thus the object of desire to make the wall invisibility is also the driving force of the story.

\section{Sender}

Sender is an act that gives a specific task to the subject. The mission given is to make the wall invisibility. This mission was given by Pak Rambo as Sham"s boss, marked by the existence of sentences that wanted Syam to make a wall that was in accordance with his will.

\section{Receiver}

The receiver or receiver is something that receives the effects of other act actions. In the TPR short story that plays a role in the receiver's acting is Mr. Rambo, marked by his efforts to give a mission to make the wall turned out to be a scourge that turns to attack him. Pak Rambo finally decided to quit, because the people"s conscience turned around to turn him over.

\section{Helper}

Helper as an actress that has a function helps facilitate the task of the subject in order to reach objects. In the TPR short story that acts as a helper is a knowledge possessed by Syam from his German school. It is proven by the existence of this knowledge that can help Syam to process the wall that Mr. Rambo wants

\section{Opponent}

Opponent is an act that blocks the subject"s task of reaching the object sent by the sender. In this case, the people of Pak Rambo become opponents who always block the subject from making a wall, until finally, the wall tries to be destroyed by the people.

The functional model expresses a story formula as a pattern of events called a function (Karnanta, 2015). At this stage of analysis will determine the functions that are important in building the storyline. By utilizing the functional model scheme, it will find a plot that moves the story into storytelling.

In its function of understanding text in depth, it is necessary to analyze meaning. According to Greimas, the reader can understand recit as a whole just by placing it into a structure and connecting it with thematic development by constructing a plot (Culler, 2002). The hope of this structural is to help the possibility of interpretation, at the next level to find the meaning of a text is to search for meaning through four-term homology. The following is an identification of four-term homology which is obtained through signs that often 
appear in the text and those in the narrative structure:
7. Conscience: Lust: Not Conscience: Not Lust

\begin{tabular}{|c|c|c|c|c|}
\hline I & & II & & III \\
\hline \multicolumn{5}{|c|}{ Transformation } \\
\hline $\begin{array}{c}\text { Initial } \\
\text { Situation }\end{array}$ & Skill Level & Main Stage & Glory & Return \\
\hline \multirow{15}{*}{$\begin{array}{l}\text { Mr. Rambo } \\
\text { (Sender) gave } \\
\text { the task to } \\
\text { Syam (Subject) } \\
\text { to make the } \\
\text { wall as good as } \\
\text { possible }\end{array}$} & Syam with the & Syam felt that he had & Pak Rambo & Mr Rambo \\
\hline & ability from the & built a wall 50 meters & finally & stopped \\
\hline & knowledge he & thick that was artistic & surrendered & serving and \\
\hline & had obtained & compared to the walls & to send a & congratulated \\
\hline & from Germany & of other houses. Even & mission to & the fight for \\
\hline & was able to & so, Pak Rambo does & make the & Syam, as a \\
\hline & continuously & not like his artificial & wall & young \\
\hline & $\begin{array}{l}\text { install Mr. Rambo's } \\
\text { wall. }\end{array}$ & $\begin{array}{l}\text { wall, because it is } \\
\text { considered a }\end{array}$ & $\begin{array}{l}\text { invisibility and } \\
\text { judge }\end{array}$ & conscience. \\
\hline & The threat & transparent wall while & that Sham is & \\
\hline & obtained from & Pak Rambo wants a & a person & \\
\hline & Pak Rambo was & high and thick wall & who has a & \\
\hline & like a whip for & that is not transparent & conscience & \\
\hline & Syam to change & & desired by & \\
\hline & and modify Pak & & his citizen. & \\
\hline & Rambo's wall & & & \\
\hline
\end{tabular}

Table 1. Functional Model According to A.J. Greimas

1. Translucent: Closed: Not Translucent: Not Closed

2. Top: Subordinate: Not boss: Not Subordinate

3. Big People: Small People: Not Big People: Not Small People

4. Well-being: Poverty: Not Welfare: Not Poverty

5. Threat: Free: Not a Threat: Not Free

6. Knife: Quiet: Disappointed: Not Calm
From the structural-semantic identification of A.J. Greimas starts from the stages of the act of relation schemes, functional models and four-term homology related to opposition and contradiction relations, showing the existence of missions from Pak Rambo which are constantly carried out according to several threats resulting in Syam as subordinates unable to resist requests from the ruler. Thus it can be concluded that the ideology or value in the short story is the hegemony of a ruler. 


\section{TPR Short Story and Matrix}

With the discovery of the value of the TPR short story, then the next step is the search for the matrix and short story model. Matrix is an invariant that appears only from a series of ungrammatical variants (Riffaterre, 1978). In the process of reading through the perspective of structural-semantic theory, there have been several events that show the ungrammatical sentence which keeps away from reality. With the search for binary opposition through three binary oppositions from the financial and fourterm homology, it appears that the matrix which becomes invariant in the text is the dominance of hegemony by the authorities. This is shown by how the inter-acting relationship moves the story. Subjects who always do work based on the will of the sender (See Scheme 1) prove the dominance of hegemony by the authorities.

Given that the matrix will not be present in the text, the present in the text is a form of actualization of the matrix or model. As in the skill phase (see table 1), Syam, who is actually a graduate from Germany working for Pak Rambo, was only to make a 'wall' and was stuck in the dominance of hegemony from his boss. There is a hidden meaning behind the words 'translucent wall', 'German graduate', 'Pak Rambo is not a small person' which appears repeatedly in TPR short stories. Coupled with the mission that must be carried out by Syam as a subject that shows his compulsion to obey Mr. Rambo's will as a boss. Then it can be concluded that the model of the TPR short story is the relationship between superiors and subordinates.

\section{TPR Short Story Hipogram}

By doing a hypogram analysis of the text of the TPR short story, it will help the reading process. By understanding fiber, mosaic and literary conventions then it will determine the success of the reader with the text of the TPR short story. The convention presented in this study is a book from B. J. Habibie titled DDYM.

In the DDYM book, B. J. Habibie explained his involvement in governance for approximately 20 years, which at that time was led by Indonesia"s second president Suharto. He was recalled from Germany to Indonesia to serve as the country"s minister of research and technology in Indonesia. The transformation of the democratic system from an authoritarian power system is told based on facts by B. J. Habibie in the DDYM book. The democratic system that has always been maintained by B. J. Habibie often receives sharp criticism from President Soeharto and his political elite.

Furthermore, to examine the hypogram of the TPR short story, the author listed the hypogram by following the pattern found previously in the structuralsemantic analysis. 


\section{Comparison}

Occupation
Desired mission
Characteristic
Final actions / actions
obtained
Actions received from an
opponent (Rakyat) (see
Scheme 1)

\section{Pak Rambo}

The Big Boss

Build the thick wall which is not transparent

Authoritarian, oligarchic, cruel, and rude

He decided to retire from his position

The citizen damaged Mr. Rambo"s wall

\section{Soeharto}

\author{
President of Indonesia \\ Form a reform committee \\ Authoritarian, strick, and wise \\ He decided to retire and serve as the \\ President of Indonesia \\ The citizen demanded Soeharto to \\ retire as President of Indonesia
}

Table 2. Comparison of Pak Rambo (Sender) and Suharto figures

\begin{tabular}{lll}
\hline \multicolumn{1}{c}{ Comparison } & \multicolumn{1}{c}{ Syam } & \multicolumn{1}{c}{ B. J. Habibie } \\
\hline $\begin{array}{l}\text { Occupation } \\
\text { Desired mission }\end{array}$ & Subordinate to Mr. Rambo & Vice Presiden of Indonesia \\
Graduated from & Germany & $\begin{array}{l}\text { Decide for the development and } \\
\text { cabinet of reformation }\end{array}$ \\
$\begin{array}{l}\text { Characteristic } \\
\text { Obedient, critical, however, his } \\
\text { obedience tends to be frightened } \\
\text { by the threat of Mr. Rambo }\end{array}$ & Obedient and critical \\
$\begin{array}{l}\text { Final actions / actions } \\
\text { obtained }\end{array}$ & $\begin{array}{l}\text { He got congratulations from Mr. } \\
\text { Rambo in struggling as a young } \\
\text { conscience }\end{array}$ & $\begin{array}{l}\text { Becoming president replaces } \\
\text { the former president (Soeharto) }\end{array}$ \\
$\begin{array}{l}\text { Actions received from an } \\
\text { opponent (Rakyat) (see } \\
\text { Scheme 1) }\end{array}$ & $\begin{array}{l}\text { The citizen never blame him as he } \\
\text { was Pak Rambo's accomplice } \\
\text { because he has a conscience }\end{array}$ & $\begin{array}{l}\text { The citizen support B. J. Habibie to } \\
\text { form a cabinet of reformation }\end{array}$ \\
\hline
\end{tabular}

Table 3. Comparison of Syam (Subject) and B. J. Habibie's Figure 
Jurnal Lakon, 9 (1) 2020

$(9-21)$

\begin{tabular}{|c|c|c|}
\hline $\begin{array}{c}\text { Event } \\
\text { Motives }\end{array}$ & TPR & DDYM \\
\hline $\begin{array}{l}\text { Initial } \\
\text { situation }\end{array}$ & $\begin{array}{l}\text { Mr. Rambo (Sender) gave the } \\
\text { task to Syam (Subject) to make } \\
\text { the wall as good as possible }\end{array}$ & $\begin{array}{l}\text { 'Untuk melaksanakan janji-janjinya Presiden Soeharto } \\
\text { menegaskan tiga hal, pertama, mempersilahkan kelanjutan } \\
\text { jalannya reformasi, kedua, memperbaiki kinerja } \\
\text { pemerintan dengan melakukan reshuffle cabinet. Dan } \\
\text { terkahir, presiden akan menggunakan wewenang untuk } \\
\text { melindungi keamanan rakyat...' } \\
\text { (Habibie, 2006, p. 11) }\end{array}$ \\
\hline Skill Stage & $\begin{array}{l}\text { Syam with the ability from the } \\
\text { knowledge he had obtained } \\
\text { from Germany was able to } \\
\text { continuously install Mr. } \\
\text { Rambo"s wall. } \\
\text { The threat obtained from Pak } \\
\text { Rambo was like a whip for } \\
\text { Syam to change and modify Pak } \\
\text { Rambo"s wall }\end{array}$ & $\begin{array}{l}\text { ','Padahal baru saja disusun Kabinet reformasi, bahkan } \\
\text { setelah melalui dialog yang cukup seru... apa yang } \\
\text { sebenarnya dikendehaki Pak Harto tentang saya? Apakah } \\
\text { saya juga diminta ikut mundur?... pernyataan pak Harto } \\
\text { sehari sebelumnya dihadapan sejumlah tokoh masyarakat } \\
\text { seolah 'meragukan' kemampuan saya.' } \\
\text { (Habibie, 2006, pp. 36-37) }\end{array}$ \\
\hline $\begin{array}{l}\text { Main } \\
\text { Situation }\end{array}$ & $\begin{array}{l}\text { Syam felt that he had built a } \\
\text { wall } 50 \text { meters thick that was } \\
\text { artistic compared to the walls } \\
\text { of other houses. Even so, Pak } \\
\text { Rambo does not like his } \\
\text { artificial wall, because it is } \\
\text { considered a transparent wall } \\
\text { while Pak Rambo wants a high } \\
\text { and thick wall that is not } \\
\text { transparent }\end{array}$ & $\begin{array}{l}\text { '...Gerakan dan tuntutan masyarakat sudah tidak sabar } \\
\text { menantikan kebebasan secara total... Presiden Soeharto } \\
\text { tidak memiliki kredibilitas lagi, dan demikian pula saya } \\
\text { yang telah mendampingi pak Harto selama seperempat } \\
\text { abad, bukankah kredibilitas dan prekdibilitas, erat } \\
\text { kaitannya dengan transparasi? } \\
\text { Bukankah transparasi itu mempermudah pengawasan? } \\
\text { Bukankah pengawangan oleh masyarakat, erat } \\
\text { kaitannya dengan kebebasan pers?' } \\
\text { (Habibie, 2006, p. } 48 \text { ) }\end{array}$ \\
\hline Stage of Glory & $\begin{array}{l}\text { Pak Rambo finally surrendered } \\
\text { to send a mission to make the } \\
\text { wall invisibility and judge that } \\
\text { Sham is a person who has a } \\
\text { conscience desired by his } \\
\text { people. }\end{array}$ & $\begin{array}{l}\text { 'Pak harto memeluk saya, dan mengatakan agar saya } \\
\text { sabar dan melaksanakan tugas sebaik-baiknya.' } \\
\text { (Habibie, 2006, p. 38) } \\
\text { 'Hari Sabtu tanggal } 23 \text { Mei 1998, pak Harto akan } \\
\text { menerima pimpinan DPR/MPR di Istana Merdeka dan } \\
\text { akan menyatakan mundur sebagai presiden.' } \\
\text { (Habibie, 2006, p. 40) }\end{array}$ \\
\hline $\begin{array}{l}\text { Final } \\
\text { Situation }\end{array}$ & $\begin{array}{l}\text { Mr. Rambo stopped serving and } \\
\text { congratulated the fight for Syam, } \\
\text { as a young conscience. }\end{array}$ & $\begin{array}{l}\text { 'Dalam ruang upacara yang sudah penuh dengan } \\
\text { wartawan dalam dan luar negeri... Pak Harto langsung di } \\
\text { tempat yang telah diatur, menempatkan dirinya, dan } \\
\text { membaca pertimbangan pengunduran dirinya sebagai } \\
\text { presiden.' } \\
\text { (Habibie, 2006, p. } 65 \text { ) }\end{array}$ \\
\hline
\end{tabular}

Table 4. Comparison of Functional Models of TPR Short stories and DDYM book 
Significance of TPR Short Stories as Transformation Texts from DDMY Notebooks

Reflecting on the results of the structural-semantic analysis on the TPR short story shows that the value or ideology in the story is the hegemony of the ruler. Relationships between superiors and bosses have unique ties. It should be noted that the definition of hegemony according to Antonio Gramsci is the historical block of the ruling class faction which applies social authority and leadership to subordinate classes by seizing agreement (Duija, 2005). Intellectual power usually becomes a tool for launching hegemony for the 'ruler' class. Resistance will eventually emerge from marginalized parties or those exposed to hegemony, the tools used can be in the form of literature, songs, mass media, and others.

In line with the creation of the TPR short story by Taufik Ikhram Jamil which can be concluded to be a tool used by marginal people to express their resistance to the new order government hegemony. Critics of social and political issues that are implicitly told cause meaning that cannot be done from heuristic readings. Autonomous reading of the TPR short story will close the meaning (significance), thus through reading with expansion in searching for the mosaic of text will help the reader to understand the text as a whole. By comparing matrices and models that are invariants of a text, and also hypograms found from both texts, the reading finds an extension of meaning.

The TPR short story is a transformation text from the events of the transition of the New Order towards the Reformation era. Although the TPR short story by Taufik Ikhram Jamil first appeared (2001), however, the book DDMY by B. J. Habibie, published in 2006, is a book that reveals records originating from historical facts. The publication was delayed because the authors and publishers waited until the social and political situation in Indonesia was conducive. The two central figures featured in the TPR short story are the transformation of the figure of Soeharto (Pak Rambo) and B. J. Habibie (Syam). TPR short stories not only provide hegemony value of the ruler of a boss and his employees who make a wall, more than that, the short story TPR tries to portray two figures who influence the transition of the New Order era to the reform era. Tembok Pak Rambo is an image of Suharto"s authoritarian leadership which has been going on for more than 30 years of his tenure as president of Indonesia. The presence of Syam figures is the image of B. J. Habibie who has a desire to provide transparency and freedom of opinion for his people. So the phrase 'translucent' here is an attempt by B. J. Habibie who embodies a transparent political plan.

The president's power is authoritarian which has been entrenched since Indonesian independence as a form of hegemony described by Barker (2005) which occurs from the process of creating meaning that is used to maintain dominating practices. On the other hand, people are increasingly developing with the advancement of knowledge and technology, causing a reaction of resistance to things such as social authority. Until finally told in the TPR short story that the people continued to destroy the walls of Pak Rambo, and when Mr. Rambo decided to quit office, the people stopped to riot. This is similar to what was expressed by B. J. Habibie in his book. Soeharto finally gave

Jurnal Lakon: Kajian Sastra dan Budaya

e-ISSN: 2527-4899; p-ISSN 2252-8954 
up on people's resistance, the chaos that occurred in the capital city of Jakarta until students who succeeded in occupying the DPR / MPR building became a form of public attack on the government's authoritarian attitude. On the other hand, the people supported the cabinet"s transparent reform draft designed by B. J. Habibie. This has become a historical event for the Indonesian people in the process of achieving a democratic system.

\section{CONCLUSION}

Autonomous reading of deep texts from TPR short stories by Taufik Ikhram Jamil raises the value of hegemony from the ruler to his subordinates. The process of expanding the meaning will be well interwoven if the reader is aware of the events that occurred in Indonesia in 1998. To get an expansion of meaning, the supporting text is presented, namely the DDMY book by B. J. Habibie.

The context of the dominance of hegemony from an authoritarian government during the New Order in Indonesia was later revealed by utilizing an intertextuality approach. TPR short stories not only tell about hegemony created by superiors and subordinates in the mission to make 'wall' but by reading the text DDMY by B. J. Habibie can expand the meaning of a story.

The meaning (significance) of the TPR short story is the new order government hegemony and the resistance of the marginal people. People's rebellion against the oligarchic and authoritarian rule was created by the marginalization of the subordinated people. Literary works are thus a tool for marginal people to voice their resistance to the authorities.

The TPR short story by Taufik Ikhram Jamil is one of the forms of criticism of the new order government as well as the appreciation addressed to B. J. Habibie for his efforts to provide transparent space as a form of supervision of the government and the formation of democracy during the transition period of the New Order to the era of the Reformation.

\section{REFERENCES}

Barker, C. (2005). Cultural Studies: Teori dan Praktik. (T. Kunci, Trans.) Yogyakarta: Bentang.

Chasanah, I. N. (2007). Representasi ReaksiKreatif Literer atas Penguasa Orde Baru dalam Kumpulan Cerpen Soeharto dalam Cerpen Indonesia. Mozaik, 1, No 1, 19-27.

Culler, J. (2002). Structuralist Poetics, Structuralism, Lingustics and the Study of Literature (Routledge Classics Edition ed.). London: Routledge.

Duija, I. N. (2005). Tradisi Lisan, Naskah, dan Sejarah: Sebuah Catatan Politik Kebudayaan. Wacana, 7 No. 2 October 2005, 111-124.

Faruk. (2017). Metode Penelitian Sastra (IV ed.). Yogyakarta: Pustaka Pelajar.

Habibie, B. J. (2006). Detik-DEtik yang Menentukan: Jalan Panjang Indonesia Menuju Demokrasi. Jakarta: THC Mandiri.

Jamil, T. I. (2001). Tembok Pak Rambo. In M. S. Anwar (Ed.), Soeharto dalam Cerpen Indonesia (pp. 29-41). Jogyakarta: Yayasan Bentang Budaya.

Karnanta, K. Y. (2015). Perempuan yang Mengundang Maut: Analisa Struktur Naratif A.J Greimas Pada Film Air Terjun Pengantin. Parafrase, 15 no $01 \mathrm{Mei}, 17-25$.

Karnanta, K. Y. (2015). Struktural dan Semantik: Teropong Strukturalisme dan Aplikasi Teori Naratif A.J 
Greimas. Atavisme, 18, No.2 Edisi Desember, 171-181.

Pradopo, R. D. (2000). Pengkajian Puisi. Yogyakarta: UGM Press.

Ratna, N. K. (2004). Teori, Metode, dan Teknik Penelitian Sastra. Yogyakarta: Pustaka Pelajar.

Riffaterre, M. (1978). Semiotics of Poetry. Bloomington \& London: Indiana University Press.

Sarup, M. (1993). Introductory Guide to Post-Structuralism and Postmodernism Second Edition. London: Harvester Wheatsheaf.

Setijowati, A. (2018). Kekerasan Simbolik dalam Nyali Karya Putu Wijaya: Karya Sastra, Politik, dan Refleksi. Mozaik Humaniora, 18 (1), 1-14.

Zohreh Ramin, S. M. (2014). History/ Fiction: An Intertextual reading of $\mathrm{E}$. L. Doctorow"s Ragtime. 3L: The Southeast Asian Journal of English Language Studies, 157-166. 